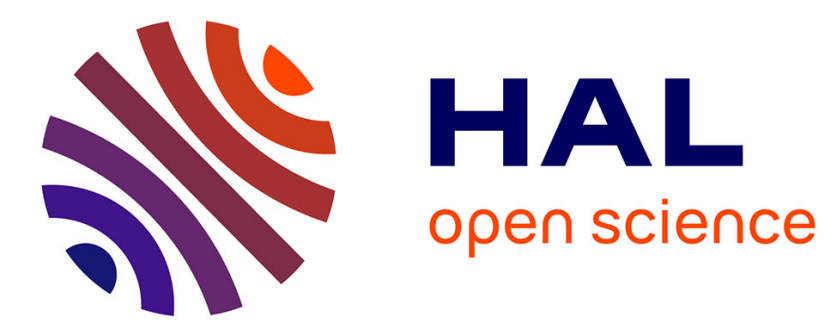

\title{
French deinstitutionalisation or the irony of success. Psychiatrists, the State and the transformation of the French psychiatric system, 1945-2010
}

Nicolas Henckes

\section{- To cite this version:}

Nicolas Henckes. French deinstitutionalisation or the irony of success. Psychiatrists, the State and the transformation of the French psychiatric system, 1945-2010. Deinstitutionalisation and After.

Post-War Psychiatry in the Western World, 2016. hal-01871497

\section{HAL Id: hal-01871497 \\ https://hal.science/hal-01871497}

Submitted on 10 Sep 2018

HAL is a multi-disciplinary open access archive for the deposit and dissemination of scientific research documents, whether they are published or not. The documents may come from teaching and research institutions in France or abroad, or from public or private research centers.
L'archive ouverte pluridisciplinaire HAL, est destinée au dépôt et à la diffusion de documents scientifiques de niveau recherche, publiés ou non, émanant des établissements d'enseignement et de recherche français ou étrangers, des laboratoires publics ou privés. 
French deinstitutionalisation or the irony of success. Psychiatrists, the State and the transformation of the French psychiatric system, 1945-2010

Nicolas Henckes ${ }^{1}$

$1 \quad$ Chargé de recherche CNRS

Centre de Recherche Médecine Sciences, Santé, Santé mentale et Société (CERMES3)

CNRS UMR8211 - INSERM U988 - EHESS - UPD

rue Guy Môquet

94801 Villejuif Cedex

nicolas.henckes@cnrs.fr

Prepublication version of: Henckes, Nicolas. "French Deinstitutionalization or the Irony of Success. Psychiatrists, the State and the Transformation of the French Psychiatric System, 1945-2010." In Deinstitutionalisation and After. Post-War Psychiatry in the Western World, edited by Despo Kritsotaki, Victoria Long and Matthew Smith. 115-33. London: Palgrave Macmillan, 2016.

Abstract: This chapter looks at the turbulent history of deinstitutionalization in France. While deinstitutionalization began later than in other western countries in France it also resulted in a highly fragmented mental health system. This chapter argue that this outcome was a consequence of the success of mental health policy from the 1960s on. Promulgated in 1960 "sectorization" policy was supposed to reorganize mental health around an array of institutions that would be able to provide adequate and continuous care to patients at any stage of the disorder. While it remained a highly innovative and very popular policy until the 1990s at least, it also proved to be a loose framework for organizing the transformation of psychiatric hospitals in this country. In the end the French mental health landscape is dominated by geographical inequalities and the invisibilization of its most vulnerable clients. 


\section{French deinstitutionalisation or the irony of success. Psychiatrists, the State and the transformation of the French psychiatric system, 1945-2010}

Nicolas Henckes

The transformations of the French psychiatric system in the second half of twentieth century pose at least two challenges to the concept of deinstitutionalisation. The first lay in the timing and pattern of the decline of psychiatric hospitalisation. Not only was a decrease in the number of psychiatric inpatient observed only after 1967, a relatively late date when compared to trends in countries such as Britain or the US, but it was widely unanticipated by mental health policies before that date. The second challenge comes from what became of the psychiatric system. If the number of hospitalised patients decreased dramatically after 1980s, from more than 110,000 to 56,000 in 2010, the extent to which one may speak of deinstitutionalisation, in the sense of a shrinking of services to psychiatric patients, or of transinstitutionalisation, referring to a transfer of care to other services, remains difficult to assess. By 2000, the cycle of reforms that had affected the mental healthcare system since the 1950s had produced an incredibly fragmented system, of which many parts remained informal and invisible. As a result, what had become of the chronic mental patient was a new, elusive question, a question that has not received an answer to date.

In this chapter I argue that the specificities of the deinstitutionalisation process in France reflected the ways in which mental health policy was negotiated by the psychiatric profession and the state. Until the end of the 1960s discussions over mental health policy were obsessed by what appeared to be an irresistible increase of the number of patients in psychiatric hospitals. For psychiatrists and the state the solution to this problem did not lie primarily outside hospitals. Rather they thought that they had to create a more efficient and humane psychiatric hospital at the centre of a diversified and integrated system that encompassed other services as well. There was little debate on where psychiatric patients had to be cared for, how many psychiatric beds were necessary, where to locate them or over the necessity of developing outpatient facilities in order to better address patients' needs. Debates over mental health policy concerned rather the question of how to plan hospital constructions, who would coordinate the system once set up and how patients would circulate through it. The policy that emerged from these debates in 1960, namely sectorisation policy, was both a relatively precise answer to these questions, and a much vaguer promise that it would produce dramatic changes in the delivery of care for mental patients. Significantly the launch of sectorisation was contemporary to the greatest effort in psychiatric hospital construction in history.

When the first statistics showing that the number of hospitalised patients had begun to decrease were published in the early 1970s, the perspective that psychiatric patients could be cared for with fewer hospital beds than current standards was beginning to gain ground among parts of the administration and the psychiatric profession. Yet this shift produced little change in the way mental health policy was thought of until 1980. Sectorisation policy had become immensely popular among psychiatrists and administrators, who saw in it a comprehensive solution to the problem of psychiatric chronicity. Advocates of sectorisation took an ambiguous if not ambivalent stance toward the downsizing of hospitals, and 
sectorisation proved to be a loose framework for fostering change in many parts of the psychiatric system. Although the disability law passed in 1975 proposed the creation of a series of services and benefits for psychiatric patients outside sectorisation, the hostility of the psychiatric profession towards the concept of disability limited their expansion.

The acceleration of deinstitutionalisation after 1980 created a quasi-anarchistic situation. Sectorisation remained the official policy in the mental health field, but it was becoming increasingly at odds both with the reality of healthcare delivery and with planning technologies developed by the Ministry of Health. An increasing number of services and facilities for people suffering from chronic mental illness were created outside sectorisation and escaped to a large extent state supervision. Many patients could not find a way through this maze and ended up in other segments of the institutional treatment of deviance.

This chapter offers a survey of this turbulent story. The first section examines the origins of sectorisation in the debates over the reform of psychiatric hospitals in the immediate post-war period. I then examine the role of construction standards in framing thinking about institutional settings of mental healthcare delivery from the early 1950s to the 1970s. The last section analyses the conflicts over the definition of care for people suffering from chronic psychiatric illness after the promulgation of the 1975 disability law and the consequences of these conflicts for deinstitutionalisation. ${ }^{1}$

\section{The politics of institutional reform}

In the immediate post Second World War period, the idea that the psychiatric system had to be reformed achieved wide consensus among both French psychiatrists and officials from the Ministry of Health. The problem had been on the agenda of the French Parliament since the early days of the Third Republic and despite heated, decade long discussions no legislative change had been achieved by the onset of the war. Numerous initiatives at the level of both local and central governments had significantly changed the outlook of the system though. Most significantly, in the interwar period dispensaries as well as so called 'open' or 'free departments' (services ouverts ou libres) to care for non committed patients had been opened by several local governments (départements). ${ }^{2}$ These efforts had been made on a voluntary basis and they had remained limited however. How to generalise them remained a conspicuous and elusive question.

The end of the war seemed to bring about an ideal set of conditions for giving an answer to this question. The quasi-revolutionary political climate that dominated France in the months following the Liberation and a more general impression that the inability of the Third Republic to modernise France had been responsible for the defeat in 1940 instilled a new reformist spirit at all levels of French society. ${ }^{3}$ The replacement of older elites with younger

\footnotetext{
${ }^{1}$ This chapter is based on research done for my PhD: N. Henckes (2007) "Le nouveau monde de la psychiatrie française. Les psychiatres, l'Etat et la réforme des hôpitaux psychiatriques de l'après-guerre aux années 1970" (Thèse de sociologie, Ecole des hautes études en sciences sociales). Accessible at: https://tel.archivesouvertes.fr/file/index/docid/769780/filename/Henckes_These.pdf

${ }^{2}$ G. M. Thomas (2004) "Open psychiatric services in interwar France" History of Psychiatry, 15, no. 2, 131-53.

${ }^{3}$ A. Kaspi (2004) La libération de la France. Juin 1944-janvier 1946 tempus (Paris: Perrin); S. Hoffmann (1974) Essais sur la France. Déclin ou renouveau? Collection Esprit "La Cité prochaine (Paris: Editions du Seuil).
} 
men and women who had often gained recognition from participation in the Resistance also seemed to remove some of the pre-war obstacles to the reform. The readiness of the psychiatric profession to participate in the creation of a better organised mental health system, contrasting with the laissez-fare attitude that dominated other segments of the medical profession, turned psychiatry into a key field for partisans of organised medicine. While it did not play the role in awaking public that would be later described in apocryphal histories, the premature death of tens of thousands of psychiatric inpatients as a result of food restriction during the war had created room for new approaches in many hospitals ${ }^{4}$. The introduction of shock therapy at the end of the 1930s and the discovery of group therapy practiced in the US and UK in 1945 also inspired a new therapeutic ethos among psychiatrists. Eventually, the fear that the number of psychiatric inpatients might continue to increase to the exceedingly high levels it had reached before the war and a sense that psychiatric hospitals were lagging behind general hospitals as a result of underfunding during the pre-war period accentuated the sense of urgency that surrounded psychiatric reform.

Despite this consensus, just how to organise reform proved to be a divisive issue. During the summer of 1945, a small group of hospital psychiatrists ${ }^{5}$ who had been involved in the Resistance organised a meeting in Paris that gathered a large number of psychiatrists in all positions from all over France. The meeting, which was later described by its organisers as the first step in a coming psychiatric revolution ${ }^{6}$, resulted in the publication of a bill to reform the psychiatric system as well as several reports and position papers that would frame discussions for the next few years ${ }^{7}$. The bill did not give practical indications regarding how to organize psychiatric services but it set forth a framework for creating a more open and integrated system in the framework of a national mental health service. In the line of pre-war discussions the project also devoted much room to rethink the admission to psychiatric hospitals. As the bill arrived on the desk of the health minister however, he also received a second bill by the influential child psychiatrist Georges Heuyer, who had been unable to participate to the meeting and contested the public health vision behind his colleagues' project. ${ }^{8}$ The Ministry of Health was unable to choose between the two bills and within months the changing political climate made a legislative solution impossible. There would be no new attempt at reforming the psychiatric legislation during the next twenty years and, from the late 1940s on, the question faced by reformers from all boards was how to achieve the reform of the psychiatric system.

Hospital psychiatrists committed to reform thought they would find a way to foster change in

\footnotetext{
${ }^{4}$ I. von Bueltzingsloewen (2007) L'hécatombe des fous. La famine dans les hôpitaux psychiatriques français sous l'Occupation Collection historique (Paris: Aubier).

${ }^{5}$ In what follows hospital psychiatrists will refer to physicians working in public psychiatric hospitals. Until the end of the 1950s, hospital psychiatrists were the only state-employed clinicians. In the immediate post-war period they formed a small group of ca 220 individuals with a strong identity and a commitment to both their institution and to clinical psychiatry.

${ }^{6}$ G. Daumézon and L. Bonnafé (1946) 'Perspectives de réforme psychiatrique en France depuis la Libération' in Congrès des médecins aliénistes et neurologistes de langue française. 44e session, Genève et Lausanne, 22-27 juillet 1946 (Paris: Masson).

${ }^{7}$ X. Abély (1945) "Avant-projet de loi sur l'assistance et l'hospitalisation des malades mentaux" Information Psychiatrique, 22, 103-11, 61-67, 88-93, 213-20.

${ }^{8}$ Conseil syndical (1945) "Les problèmes psychiatriques actuels" Information Psychiatrique, no. 4, 51 sq.
} 
the system on the basis of initiatives at the local level. In the late 1940s several of them began to experiment with new ways of practicing psychiatry with the few available means they had, including some funding from the newly created Social Security. The most influential of these experiments were a series of attempts at transforming the atmosphere in wards through the means of occupational therapy and group techniques inspired by British and US group psychotherapy. By the late 1940s these attempts were theorised under the concept of 'institutional psychotherapy', a concept that soon became immensely popular among hospital psychiatrists and well beyond. ${ }^{9}$ Other psychiatrists also created outpatient services as an extension of their hospital activities. One important initiative in the Paris region was the creation of a network of mental hygiene centres under the direction of hospital psychiatrists from the late 1940 s on. ${ }^{10}$ Other noteworthy experiments included therapeutic homes and workshops. ${ }^{11}$ By the late 1950s these experiments constituted a reservoir of interesting innovations but they contributed little to a comprehensive reform. And while they did challenge the institutional order of psychiatric hospitals, they did not contest their role in the treatment of psychiatric illness.

The possibility of a political solution began to resurface in 1947 when the Ministry of Health appointed a commission to produce advice on mental health problems, the Commission for the Study of Mental Health Problems, which would remain famous under the name it received after its reorganisation in 1949, the Commission of Mental Illnesses. ${ }^{12}$ The Commission comprised a majority of psychiatrists representing the diverse sensibilities in the profession, as well as representatives from the various administrations interested in psychiatric matters and was presided over by a psychiatrist. Until 1960, the Commission met on average every three months to discuss decrees, projects from the Ministry of Health or general questions put on the agenda by the Ministry or by psychiatrists themselves. Over the years, discussions at the Commission inspired a series of measures regarding numerous aspects of the organisation of psychiatric hospitals and psychiatry at large. Its work culminated in the second half of the decade with a series of discussions that prepared the promulgation of sectorisation policy in 1960 .

Sectorisation emerged as an answer to a very practical question. In the early 1950s the French government had decided to invest massively in the health system in the framework of the new planning infrastructure that had been created by Jean Monnet to reconstruct France in the

\footnotetext{
${ }^{9}$ G. Daumézon and P. Koechlin (1952) "La psychothérapie institutionnelle contemporaine" Anais Portuguese de psiquiatria, 4, 271-311.

${ }^{10}$ N. Henckes (2005) 'Réformer la psychiatrie, organiser les pratiques de secteur. La construction de la psychiatrie de secteur dans "l'expérience du treizième arrondissement"' (Rapport pour le programme Sciences biomédicales, Santé, Société, MiRe/INSERM/CNRS).

${ }^{11}$ For instance: E. Diébolt (1997) De la quarantaine au quarantenaire, histoire du foyer de postcure de l'Élan (Paris: Editions de l'Elan Retrouvé).

${ }^{12}$ Almost all the minutes of the Commission and most of the reports presented during sessions were published by hospital psychiatrists in their professional journal L' Information Psychiatrique. Missing items can be found in the national archives, 19950173-1. The reorganisation of the Commission in 1949 was a consequence of its incorporation in the larger Permanent Council on Social Hygiene, one of the two main advisory councils of the Ministry of Health, which had been established in 1938.
} 
immediate post-war period. ${ }^{13}$ For the administration, the question was how to rationally plan the renovation and construction of the psychiatric system: where, how, and according to which architectural design should hospitals be constructed? To what extent should the psychiatric system also comprise of other types of services? And who should make such decisions? The ministerial circular that launched sectorisation policy on 15 March 1960 could be read as a guideline regarding how to address these diverse questions. ${ }^{14}$

At the meetings of the Commission of Mental Illnesses, two factions coalesced around two rather different answers to these questions. The first aligned itself behind the small group of hospital psychiatrists who had organised the 1945 meetings. For them, planning should be organised from below, under the responsibility of a clinical psychiatrist - when possible a psychiatrist working in a public psychiatric hospital - in charge of devising the system. ${ }^{15}$ The first step of the process was to create outpatient services, notably consultations, and it was only as a last step that the construction of hospitals should be considered. For their opponents, whose leaders were a small group of university based psychiatrists, the Ministry of Health had to give clear standards regarding how to construct hospitals. ${ }^{16}$ The first issue to address was the institutionalisation of chronic and incurable patients in hospices in order to create room for the treatment of acute patients in hospitals. Day hospitals and other alternatives to hospitalisation could be envisioned but only at a later stage of the planning process. Both groups also diverged on the meaning of hospitalisation. Hospital psychiatrists thought of the psychiatric hospital as a facility for social rehabilitation. Their opponents insisted on the need to think of hospitals as highly technological institutions in charge of delivering cutting edge treatments, including the emergent and increasingly numerous chemotherapeutic and biological treatments.

Ultimately, sectorisation was a compromise between both perspectives. The 1960 circular entailed at once a methodology to plan psychiatric institutions and a rationale to manage the system. It was both a guideline and a policy statement. Local governments had to establish plans on the basis of propositions made by hospital psychiatrists and any other interested parties. The programme had to entail the creation of a series of catchment areas attached to psychiatric hospitals, the so-called sectors (secteurs). Each sector should be placed under the responsibility of a unique medico-social team, led by a senior psychiatrist from the hospital to which it was attached, in charge of managing hospital beds as well as community services. Local plans were then to be sent to the Ministry of Health to be reviewed by a commission. They were not constraining but they were supposed to stimulate local initiatives.

The idea of coordinating outpatient facilities and inpatient departments through a unique medical direction was the main innovation of the policy. For psychiatrists it was the crux of

\footnotetext{
${ }^{13}$ H. Rousso (ed. (1986) De Monnet à Massé. Enjeux politiques et objectifs économiques dans le cadre des quatre premiers Plans (1946-1965). Actes de la table ronde tenue à l'IHTP les 24 et 25 juin 1983 (Paris: Editions du CNRS); B. Jobert (1981) Le social en plan (Paris: Editions ouvrières).

${ }^{14}$ Circulaire du 15 mars 1960 relative au programme d' organisation et d' équipement des départements en matière de lutte contre les maladies mentales.

${ }^{15}$ L. Bonnafé et al. (1957) "Rapport sur l'équipement psychiatrique d'un territoire dépourvue de toute formation spécialisée" Information Psychiatrique, 33, no. 6, 299-311.

16 J. Dechaume, unpublished note, Commission on mental disorders, meeting of the 19 December 1955. Archives Nationales 19950173-1.
} 
what they called 'sector psychiatry', a radically new way of practicing psychiatry in sectors. The circular gave a list of outpatient services that could be set up, such as day hospitals, therapeutic workshops and dispensaries. These services were not seen as alternatives to hospitals in the sense that they would make it possible to discharge patients stuck in hospitals. But they were supposed to help ameliorate the circulation of patients in the system and thus contribute to its efficiency. Early treatment in dispensaries and aftercare treatment in therapeutic homes were also supposed to reduce unnecessary hospitalisation. Ultimately an efficient mental health system would prevent chronicity. But as we shall see the creation of an array of non-hospital psychiatric services was not considered a reason for planning a reduction in hospital beds.

\section{The rise and fall of construction standards}

The 1960 circular consecrated two important standards that encapsulated the prominent role attributed to psychiatric hospitals in mental health policies in mid-twentieth century France. The first was an architectural model, namely the cottage hospital; the second, a statistical norm, the ratio of three psychiatric beds per thousand population. Both standards had circulated before 1960 but their mention in the circular put them in full view. In the next few years they would be a key ingredient in what was probably the biggest construction effort in the history of French psychiatry. When, by the turn 1970s, the role of psychiatric hospitals in the treatment of psychiatric patients began to be contested, the absence of similar standards for outpatient services left mental health planning without strong standards, giving way to a chaotic deinstitutionalisation process.

The cottage model for psychiatric hospital construction, or in French the hôpital village, was an output of discussions in the immediate post-war period although it had its origins in discussions dating back from the early twentieth century. ${ }^{17}$ The model meant that hospitals should comprise of a series of small constructions gathered around central medical and administrative services. It contrasted with the model for hospital construction in the rest of medicine, namely the 'block hospital' model. The cottage model was coherent with a vision of psychiatric hospitals as a place for social rehabilitation. What had been before the war an architectural metaphor was now taken extremely seriously: hospitals had to be true villages that provided a meaningful social life to patients in order to help them readapt to society. The cottage model implied that constructions needed large grounds and henceforth had to be constructed outside urban centres. Since there was also a consensus that hospitals needed to be accessible from cities, the conclusion was that psychiatric hospitals had to be established in suburban areas and be accessible with public transportation. Hospital psychiatrists also insisted that construction should be small in size, with units accommodating for not more than 50 beds, and the whole institution not more 300 beds, but these recommendations were disputed by hospital directors who argued that small hospitals were economically non-

\footnotetext{
17 J. Lauzier et al. (1946) Au delà de l'asile d'aliéné et de l'hôpital psychiatrique. Documents de l'Information Psychiatrique, 2 (Paris: Desclée de Brouwer). For a history of the model in France see: P.-L. Laget (2004) "Naissance et évolution du plan pavillonnaire dans les asiles d'aliénés" Livraisons d'histoire de l'architecture, no. 7, 51-70.
} 
viable. ${ }^{18}$ In practice, hospitals built between 1950 and 1960 often exceeded this standard.

Another motive behind the discussions over the size of hospitals was the widespread perception that the French psychiatric system lacked sufficient beds to meet needs. This perception was encapsulated in the ratio of three psychiatric beds per thousand population as the objective for mental health planning in the 1960 circular. Since the last third of the nineteenth century national statistics had documented the steady increase in the number of hospitalised patients and the phenomenon did not seem to halt. In the interwar period most psychiatric hospitals were facing overcrowding. In the post-war period health authorities set to gain control over the phenomenon. The newly created psychiatry section at the National Institute of Hygiene endeavoured to explain the steady increase in the number of hospitalised patients with the help of statistical methods. ${ }^{19}$ These studies seemed to demonstrate that the biggest contribution to this increase was a rise in the number of cases of reactional psychosis, a phenomenon that was related to the modernisation of France. As a result a decline in the number of hospitalised patients was not to be anticipated.

The two first national construction plans in 1953 and 1957 were devised with reference to an increased rate calculated on the basis of past experience. The reference to the figure of three beds per 1000 inhabitants in the 1960 circular demonstrated the will of the Ministry of Health to set clearer objectives to local authorities. The figure was cited after a report by the World Health Organization on psychiatric hospitalisation published in $1953^{20}$ but its strength in the French context came from the way it resonated with the interests of the administration: it was a simple and telling standard that was slightly over current statistics - France counted 2.5 beds per 1000 inhabitants in 1960 - so that it seemed both reasonable and still high. Although French psychiatrists might have played a key role in its inclusion in the WHO report, the fact that the figure was cited by an international document made it an indisputable norm. ${ }^{21}$ Comparisons were also made with countries with a higher numbers of beds such as Switzerland or Nordic countries.

The promotion by health authorities of both the cottage model and the three beds per 1000 inhabitant statistics testified to their commitment to funding psychiatry at a high level. In 1957 the government indicated that psychiatry should attract 30 per cent of all investments in the health sector. Five years later, the Fourth Plan set an objective of constructing 22,630 hospital beds by 1965 and the next plan reaffirmed the objective of creating 18,000 beds by 1970, while it also planned the renovation of 20,000 beds. $^{22}$ Even though actual expenditures and constructions were significantly less than planned, the number of constructions rose

\footnotetext{
18 "Commission des Maladies Mentales. Séance du 29 juin 1954" (1954) Information Psychiatrique, no. 3, 14955.

${ }^{19}$ H. Duchêne (1949) 'La statistique des hôpitaux psychiatriques. Travail de l'Institut National d'Hygiène'. Unpublished Report at the Commission des maladies mentales, $24^{\text {th }}$ May 1949, Archives Nationales, 19950173-1

${ }^{20}$ World Health Organization (1953) The Community Mental Hospital. Third Report of the Expert Committee on Mental Health Technical Report Series No. 73 (Geneva: World Health Organization).

${ }^{21}$ N. Henckes (2009) "Narratives of change and reform processes: Global and local transactions in French psychiatric hospital reform after the Second World War" Social Science \& Medicine, 68, 511-18.

${ }^{22}$ Commissariat général au plan (1961) Quatrième plan de développement économique et social (1962-1965). Rapport général de la Commission de l'équipement sanitaire et social (Paris); Commissariat général au plan (1966) Cinquième plan, 1966-1970. Rapport général de la commission de l'équipement sanitaire et social. (Paris: La documentation française.).
} 
sharply. ${ }^{23}$ From 1956 to 197230 new psychiatric facilities were opened across the country, totalling 13,400 beds in 19 specialised hospitals and 11 psychiatric departments in general hospitals. ${ }^{24}$ In 1972 7,290 new beds were still in construction. These constructions enabled the steady increase of hospitalisation numbers during the 1960s. The number of hospitalised patients reached a peak in 1967 totalling 120,000 by the end of that year. ${ }^{25}$

Voices anticipating that psychiatry could do with fewer beds were rare but nonetheless significant in the early 1960s. In 1958 the Ministry of Health launched a survey on the impact of the new neuroleptic chemotherapies on inpatient populations. While its results - which were not published - demonstrated acceleration in the annual number of discharges, they did not suggest a decrease in the number of patients. ${ }^{26}$ In the next few years advocates of the psychopharmacological revolution such as Jean Delay and Pierre Deniker, who had first described the 'neuroleptic' effects of chlorpromazine, set to demonstrate that psychotropic drugs had tremendous effects on psychiatric hospital demography, but these views attracted only limited support in the profession.

More significant, and more consequential for construction standards, were a series of pioneering experiments in sector psychiatry launched in the 1960s. The first, and for decades the most influential of these was created in Paris $13^{\text {th }}$ arrondissement at the turn of 1960 under the aegis of an association, the Association de Santé Mentale et Lutte contre l'Alcoolisme dans le $13^{\text {ème }}$ arrondissement de Paris (ASM13), and with massive support from local authorities, the Ministry of Health as well as Social Security funds. The founder of ASM13, Philippe Paumelle was a hospital psychiatrist who had stopped working in psychiatric hospitals to work for the office of mental hygiene at the Préfecture de la Seine in 1954. Paumelle counted among the most virulent critiques of psychiatric hospitalisation the time. In the $13^{\text {th }}$ arrondissement he wanted to create ex nihilo an institutional system that would be able to address all the mental health needs of the population without relying on existing psychiatric hospitals.

Paumelle did not envision working without hospitals however. In fact the first facility opened by the ASM13 after the consultation centre was a hospital, constructed in the rural city of Soisy-sur-Seine located $30 \mathrm{~km}$ south from Paris. The hospital was a typical exemplar of the cottage model. But Paumelle wanted to make with fewer beds than current standards. Instead of three beds per 1000 inhabitants, the ASM13 would meet the needs of the $13^{\text {th }}$ arrondissement with only 150 beds for a total of 150,000 inhabitants in the thirteenth arrondissement, that is exactly 1 bed per 1000 inhabitants. In Paumelle's view, however, working with this small number was only sustainable if the Association could count on a diversity of outpatient services. The plan published by the Association in 1964 mentioned a total of 726 beds and places (lits et places), places referring to positions in day care facilities, including 120 beds in a therapeutic nursing home, 50 beds in a nursing home for elderly

\footnotetext{
${ }^{23}$ A survey of psychiatric constructions in the 1960s and 1970s still has to be done.

${ }^{24}$ C. Laurenceau (1972) "Inventaire des moyens psychiatriques existant en France" Information Psychiatrique, 48, no. $10,975-80$.

${ }^{25}$ F. Chapireau (2007) "Le recours à l'hospitalisation psychiatrique au XXe siècle" Information psychiatrique, 83, no. 7, 563-70.

26 'Enquête sur la Consommation des Neuroplégiques dans les Hôpitaux Psychiatriques', August 1958, Archives Nationales, 19950173-2.
} 
patients, 91 places in day hospitals, 240 places in workshops, and 50 places in familial placement, totalling 295 beds, that is two beds per 1000 inhabitants.

The hospital opened its first buildings in 1963 and reached full capacity in 1968. Creating services in Paris proved much more complicated both because empty locales were missing or too expensive in the $13^{\text {th }}$ arrondissement and because obtaining authorisation from regional and national health and financial authorities proved arduous given the experimental nature of most of the planned facilities. By 1970 the institutional armamentarium of the ASM13 comprised 429 beds and places including 279 beds in the hospital and a nursing home. ASM13 services experienced a period of acute overcrowding in the early 1970s when the Association had to take over care for a number of chronic patients from the $13^{\text {th }}$ arrondissement who had been hospitalised in other psychiatric hospitals in the region earlier but the situation came under control by the end of the decade.

Despite its leaders' rhetoric, the financial situation of the ASM13 was much too exceptional for it to constitute a generalisable model. In 1967 local authorities still mentioned the standard of three beds per 1000 inhabitants when they devised a new scheme for planning sectorisation in the Paris region. ${ }^{27}$ The scheme detailed a complex organisation. Since all psychiatric hospitals accessible to the Parisian population were located outside the city with the exception of the Sainte Anne hospital, and since sectorisation policy implied that psychiatric services had to be located in the communities, the plan proposed that each sector be attached to two hospital departments, one, totalling 50 beds, in the Sainte Anne Hospital, and the other totalling 150 beds located in a suburban institution. Since all sectors were supposed to comprise approximately 70,000 inhabitants, the total number of beds matched exactly the standard of three beds per 1000 inhabitants. In addition, consultations centres, therapeutic homes and workshops, and day care facilities had to be constructed in the sectors.

The first sector following this model was created in Paris $6^{\text {th }}$ arrondissement in 1968 but it rapidly proved to be a failure. The psychiatrist in charge of the service, Paul Bernard, found it impossible to manage two hospital wards in two different hospitals. Outpatient services had been slow to open so that Bernard felt he had been betrayed by his administration. On the other hand he realised that the psychiatric needs of the $6^{\text {th }}$ arrondissement could be addressed with 75 beds in Sainte Anne. This novel organisation was implemented in early 1969. Another sector was created in 1969 with the same number in beds located outside Paris in the PerrayVaucluse hospital for the $7^{\text {th }}$ arrondissement. In 1969 a document from the administration of the Paris region proposed a revised standard. Proposals should plan for a combination of beds and places totalling three per 1000 inhabitants.

By 1970 the cottage model had also become increasingly contested. Several calls for rethinking an architectural design compatible with a urban setting were published in psychiatric journals in the late 1960 s. $^{28}$ An influential proposal planned to construct hospitals

\footnotetext{
${ }^{27}$ A first scheme had been devised in 1963 but it had to be revised because of a reorganisation of the Parisian local government. The analyses in this paragraph and the next are based on the archive of the Direction de l' Action Sociale, de l' Enfance et de la Santé, Archives de Paris, call number 1513W.

${ }^{28}$ N. Sonolet (1966) "Un centre de santé mentale. Point de vue et proposition d'un architecte" Information Psychiatrique, no. 6, 527-32 ; G. Ferrand and J.-P. Roubier (1967) "L'hôpital psychiatrique dans la cité:
} 
in buildings that would also comprise housing, offices and shops. Other publications suggested the development of psychiatric services in general hospitals. In 1971 a ministerial circular officially declared that constructions should no longer follow the cottage model and that wards should be opened in general hospitals. ${ }^{29}$ Large psychiatric hospitals were no longer an ideal. $^{30}$

\section{The irony of success. Deinstitutionalisation and the limits of mental health policy}

Despite the evolutions of local and national policies, deinstitutionalisation was still hardly an issue in public debates by the late 1970s. This changed dramatically when, in 1980, Jacques Barrot, the health minister in the last government of the conservative President Valéry Giscard d'Estaing called for the closing of 40,000 psychiatric beds out of the existing 100,000. Although these figures were not very different from the standards circulating at the time, the ministerial call provoked a fierce reaction among psychiatrists, a reaction that was not entirely explained by the poor popularity of the minister among a profession that clearly leaned to the left. $^{31}$ Psychiatrists deplored the fact that the minister was only motivated by financial concerns and, above all, that he had not mentioned sectorisation. Sectorisation, in their view, remained the best way to adapt the psychiatric system to both the progress of the discipline and evolving patients' needs.

Psychiatrists' reaction to the ministerial call reflected the immense popularity sectorisation had acquired among the profession well beyond the small circle of hospital psychiatrists who had initially promoted it. In 1964 an influential report by three prominent reformer psychiatrists argued that sectorisation was the only way to address the needs of people with chronic mental illness and to enable them to function at their highest level. ${ }^{32}$ Sectorisation also became a key ingredient in the professional identity of psychiatrists. In 1968, after years of demonstrations and mobilisations, psychiatrists secured separation from neurologists, to whom they had been associated since the 1940s, to constitute an independent medical specialty. Advocates of the reform argued that psychiatry represented a specific way of practicing medicine that needed a specific organisation. Since ideas of comprehensive care and proximity were at the core of its philosophy, sectorisation was precisely this organisation. $^{33}$

Sectorisation played no small role in the successes of the discipline in the next few years. The 1968 reform had turned psychiatry into a highly attractive discipline, not the least because it had given sectors an important role in the training of psychiatrists and other mental health

programme d'un hôpital psychiatrique urbain de moins de cent lits" Recherches, special issue "Programmation architecture et psychiatrie", June 1967, 35-136.

${ }^{29}$ Circular 148, 18 January 1971. See M. Audisio (1980) La psychiatrie de secteur. Une psychiatrie militante pour la santé mentale (Toulouse: Privat).

${ }^{30}$ The last psychiatric hospital following the cottage model opened in 1983 in the Paris region however.

31 J. Ayme (1995) Chroniques de la psychiatrie publique à travers l'histoire d'un syndicat (Ramonville-SaintAgne: Erès).

${ }^{32}$ L. Le Guillant, L. Bonnafé, and H. Mignot (1964) 'Problèmes posés par la chronicité sur le plan des institutions psychiatriques. Rapport d'assistance' in Congrès de psychiatrie et de neurologie de langue française. LXIIe session. Marseille 7-12 septembre 1964. Comptes rendus. Tome II ed. Pierre Warot (Paris: Masson et Cie éditeurs).

${ }^{33}$ Livre Blanc de la Psychiatrie Française (1966-1968) 3 vols. (Toulouse: Privat) and C. Brisset (1972) L'avenir de la psychiatrie en France (Paris: Payot). 
professionals. The psychiatric profession grew spectacularly from 1,000 practitioners in 1970 to more than 10,000 in 1990. A new breed of psychiatrists was emerging who conceived of themselves as true entrepreneurs and who, thanks to still empathetic and supportive administrations, developed numerous innovative experiments in sectors, such as crisis centres, various forms of day care facilities and home treatments. Many of these experimental services became models far beyond psychiatry, and sectorisation itself inspired policies in the delivery of healthcare for a variety of populations, from cancer to AIDS and care for elderly people.

By the 1990s, however, the cost of these successes had become increasingly visible. An influential report to the Minister of Health published in 1992 demonstrated that sectors were the sites of extreme inequalities. ${ }^{34}$ More than 800 sectors had been created throughout France and if a few of them comprised a number of outpatient services located in communities, the majority had few alternatives to hospitalisation. Even more worrying, many sectors in rural areas still consisted solely of services in large psychiatric hospitals located at a distance of communities and with extremely long duration of stay. While sectorisation policy was supposed to provide higher levels of integration in the psychiatric system, it was in fact creating inequality. And it had proved unable to transform large psychiatric hospitals.

The reasons for these shortcomings were easily identified. In 1983, after years of discussion, the government decided not to institutionalise a formal structure to administer sectors and to give hospitals financial control over outpatient services created in sectors. While this decision did not much change the situation of sector services at first, it soon proved deleterious. As finances became increasingly constrained, hospital directors became reluctant to spend money in services that, in their view, were not the raison d'être of their institution. Nursing homes and workshops created in the framework of sectorisation were particularly vulnerable to this logic. On another hand, legislations treated outpatient services created in sectors as optional. Except for the creation of consultation centres, no standard was given by the administration. A nomenclature was published in 1986 but it was clearly thought of as a repertoire of possible options, rather than a list of recommended services. ${ }^{35}$ The list was supposed to be updated as new experiments created new models, but this never happened.

Several reasons explained why sectorisation policy was not more coercive. The government did not want to commit itself to providing the financial support needed to match the standards it would have imposed. Psychiatrists were also reluctant to see administrations set strong standards regarding the organisation of their work. According to them different populations needed different services and as a result it was impossible to declare universal standards. On the other hand psychiatrists insisted that the role of sectorisation policy was to stimulate the creativity of mental health workers, not to set rigid regulations. It was clear, however, that psychiatrists also sought to preserve their autonomy. Significantly the main outcome of the debates around the 1992 report was the creation of an agency supposed to audit sector

\footnotetext{
${ }^{34}$ G. Massé (1992) La psychiatrie ouverte. Une dynamique nouvelle en santé mentale. Rapport au Ministre de la Santé et de l'Action Humanitaire (Rennes: Editions de l'Ecole Nationale de la Santé Publique).

${ }^{35}$ (1986) 'Arrêté du 14 Mars 1986 Relatif aux Équipements et Services de Lutte contre les Maladies Mentales Comportant ou non des Possibilités d’ Hébergement', Journal Officiel de la République Française, 19 March 1986, pp. 4620-4621.
} 
services and provide them with advice in order reform their structures. ${ }^{36}$

The shortcomings of sectorisation policy were clearly an impetus for the creation of alternative ways of delivering care to psychiatric patients. This did not happen without difficulty however. In 1975 the government passed a comprehensive disability law that, for the first time, sought to address all the needs of disabled people, from school to employment, through accessibility to public buildings and housing. ${ }^{37}$ The law created a series of rights, services and institutions, including nursing homes, workshops and benefits, outside the existing infrastructure of hospitals and social security services. A crucial motive behind the legislation was that many disabled people were cared for in hospitals, and especially psychiatric hospitals, where they did not belong. While the official line was that disability and illness were two related concepts, in effect the law created a divide between health and social services for disabled people. A second law promulgated the same day as the disability law organised planning and funding for disability services. ${ }^{38}$ The objective was to create an institutional infrastructure that mirrored the organisation of health institutions. In the end planning was even less efficient than in the field of hospitals.

Psychiatric patients were eligible to some of the new disability services: they could access disability benefit and the disability law also created a new category of nursing homes specifically designed for them. These services were promoted by family associations and the government as the first true alternatives to the psychiatric management of mental illness. ${ }^{39} \mathrm{By}$ contrast, psychiatrists interpreted the law as an attack against both sectorisation and themselves. If the new disability services were supposed to employ some medical personnel, including psychiatrists, they were not directly under their supervision and, moreover, they were only accessible through a procedure monitored by a special, non medical commission. By the end of the 1970s psychiatrists managed to overturn most of the measures related to psychiatric patients in the disability law, especially those concerning the creation of nursing homes. $^{40}$

In subsequent years, however, psychiatrists could not prevent the gradual development of a series of services and institutions targeting their patients through the framework of the 1975 laws. By 2000 these services had become a significant force in the institutional management of people with mental illness, and their integration with sectorisation was a major concern for health authorities. Most of these services resulted from local initiatives and were managed by voluntary and charity organisations, including family associations, a possibility that was encouraged by the 1975 laws. They were also often accessible to people with a diversity of problems that were not always framed in terms of mental health. Authorities had usually only limited knowledge about their activities and no comprehensive directory was available. As a result their distribution over the territory was even more uneven than that of sector mental

\footnotetext{
${ }^{36}$ The Mission Nationale d'Appui en Santé Mentale, which operated until 2013.

${ }^{37}$ (1975) Loi n ${ }^{\circ}$ 75-534 d'Orientation en Faveur des Handicapés, Journal Officiel de la République Française, 1 July 1975, pp. 6596-6604.

${ }^{38}$ (1975) Loi n 75-535 du 30 Juin 1975 Relative aux Institutions Sociales et Médico-sociales, Journal Officiel de la République Française, 1 July 1975, pp. 6604-6607.

${ }^{39} \mathrm{~N}$. Henckes (2012) "Entre maladie et handicap: repenser la critique psychiatrique de la loi du 30 juin 1975 d'orientation en faveur des personnes handicapées" ALTER, European Journal of Disability Research, 6, 242-54. ${ }^{40}$ Ibid.
} 
health services. Although service planning had been a crucial dimension of mental health policy since 1945, many dimensions of the delivery of mental healthcare now escaped state supervision.

\section{Conclusion}

By 2014 the number of psychiatric beds had been reduced to 55,800, including 36,000 in public hospitals. ${ }^{41}$ France still counted 88 public psychiatric hospitals totalling 26,700 beds, some of which still occupied buildings that had been constructed in the first half of the nineteenth century, and most of the hospitals constructed over the last two centuries were still in service. But psychiatric hospitals had little in common with the total, desperate institutions they had been just a few decades earlier. Deinstitutionalisation in that sense had been a massive reality.

More than the dramatic transformations of the pattern of psychiatric hospitalisation, however, what has dominated French debates over deinstitutionalisation in the last seventy years was the coordination and integration of services for people with mental illness in the framework of a comprehensive mental health policy. The objective of both the psychiatric profession and health authorities was to shape integrated pathways to care that would address the needs of patients at every stage of their illness, in all the dimensions of their life.

In that respect French mental health policy was a failure. The cycle of reforms that has affected the mental health world since the 1960s has produced an incredibly complex and fragmented landscape of institutions and services, one over which no one has an overview today. In this chapter I have argued that this failure of mental health policy was an ironical outcome of its very successes. The early successes of sectorisation policy and its enduring popularity among both mental health professionals and the health administration prevented both groups from anticipating and monitoring alternatives to the psychiatric management of patients. As a result, while for most of the last sixty years mental health policy targeted patients with chronic mental illness, in many ways they have become invisible in a system that is to a large extent unable to acknowledge the very existence of their enduring difficulties.

\footnotetext{
${ }^{41}$ Direction de la recherche des études de l'évaluation et des statistiques (2014) Le panorama des établissements de santé Collection Etudes et Statistiques (Paris: Ministère des Affaires Sociales, de la Santé et des Droits des Femmes).
} 
C

Chronic mental patients, 1

Disability Law (Loi 75-534 d' orientation en faveur des handicapés) 1975, 2

$\mathbf{S}$

$\mathbf{F}$

Sectorisation, 1

France, 1

$\mathbf{L}$

$\mathbf{T}$

Transinstitutionalisation, 1

Legislation 